Publisher homepage: www.universepg.com, ISSN: 2663-7820 (Online) \& 2663-7812 (Print)

https://doi.org/10.34104/cjbis.019.01727

Canadian Journal of Business and Information Studies

Journal homepage: www.universepg.com/journal/cjbis

\title{
Present Scenario of Human Resource Management (HRM) Practices in the Life Insurance Companies: Bangladesh Perspective
}

\section{Mohammad Milon*}

Dept. of Human Resource Management (HRM), Jatiya Kabi Kazi Nazrul Islam University, Trishal, Mymensingh, Bangladesh.

*Correspondence: milon07mgt@gmail.com

\begin{abstract}
To keep the economic challenge in Bangladesh fast and active with other financial and non-financial companies, the insurance companies are playing a crucial contribution to our wealth. This economic contribution, no doubt, could be more effective in economy, if our insurance companies could able to apply HRM philosophy in its all spheres. In true sense, the concept of HRM practices are not widely applied aspects in many insurance companies still in our country due to some pivotal shortcomings. The aim of study was to identify the present scenario (good/poor) of HRM application in the life insurance companies in our country. The study was limited to 10 life insurance companies in our country comprising all branch offices in Dhaka city. To collect relevant data, a comprehensive questionnaire (Liker Scale) was circulated among 220 respondents. The respondents were officers and branch managers. The most striking results of HRM practice was unsatisfactory/poor in all life insurance companies for the reasons of employees' absenteeism, employees' turnover, inadequate training facilities, lack of motivational tools, inadequate welfare facilities, absence of performance rating system, etc. It is recommended that, the life insurance should keep good HRM practice to minimize their employees' absenteeism and turnover. Secondly, the companies can arrange adequate trainings (on-the-job \& off-the-job) facilities for their existing employees. Then, the life insurance can practice a positive motivation, leadership, and adequate welfare facilities for their human resources. Finally, the companies can maintain performance evaluation system in regular for minimizing their poor HRM practices.
\end{abstract}

Keywords: HRM concept, Life Insurance Companies, HRM Functions, and Good/Poor HRM.

\section{INTRODUCTION:}

In recent time in our country, HRM applications are the blessing part of all life insurance companies. Because HRM practices in the life insurance work out some crucial issues such as equal employment opportunity; sexual harassment; employment at will; glass ceiling; affirmative action; conflict \& negotiation; absenteeism \& turnover etc. problems (Ahmed, 1977). Apart from the above contemporary issues, According to (Ali, 2013) HRM is the best solution of proper recruitment, selection, training, development, performance rating, job design, job analysis, job evaluation, compensation management, health and safety of employees etc. for every insurance company. Moreover, (Arthur, 1994) indicate that people are more concerned about their present and future protection for various purposes such as life protection, health protection, education protection and so on (Jony et al., 2019). In this regard, people are getting assurance \& future guarantee from life 
Insurance companies in many ways (Charumathi, 2012). Consequently, life insurance companies are providing the unique financial services to the growth and development of our economy by keeping pace with the other financial industry. Ahmed et al., (2010) argues that today's business world without insurance assurance is unsustainable since business may not have the capacity to retain all kinds of risks in this ever changing and uncertain global economy, only HRM applications as an emerging issue are the key factors for bringing success of any insurance company. Undoubtedly, HRM is the part of the organization concerned with the "people/manpower" dimension and regarded as human is a capital (Dessler \& Varkkey (2011).

A good practice of HRM in insurance companies ensures the right persons for the right position who will able to turn organizational opportunities into productivity. In the word of Ulrich and Lake (1991), organizational capability assures to hire and retain competent employees and developing their competencies through effective human resource management practices. Exactly, developing a skillful workforce is essential to sustainable competitive advantage in any insurance companies (Kundu and Vora, 2004). According to Becker (1993), HRM is about valuing the role of people to bring the benefit of an organization, and the term 'human capital' describes the results by human capacity, skill and knowledge for manufacturing of goods and services.

In addition, Khatri (1999) told that, people are one of the most pivotal capital providing flexibility and adaptability to organizations. In the same way, Stavrou-Costea, (2005) argued that, people (managers), not the firm, are the adjustment factors in fixing how the firm will respond to the cutthroat environment. HRM can help firms to improve behavior with staff commitment, competency, and flexibility which in turn leads to improved staff execution (Koch and McGrath, 1996). People should be regarded as assets rather than variable costs (Ejaz and Akbar, 2015). In the word of (Khnodkar and Rahman, 1993), human resources are valuable and a source of competitive advantage. BIA (2012) stated that, people and their collective skills, abilities and experience are now recognized as making a significant role to organizational triumph and as constituting a major source of competitive advantage. The main reason of this study is to highlight present scenario (Good/Poor) of HRM applications in some selected life insurance companies in our country. At the same time, some effective measures and suggestions will be added based on research findings for good HRM applications in all the life insurance in Bangladesh.

\section{Justification of Research:}

The life insurances of our country are the pivotal part of our present economy. The phenomenal aspect of our economy could be more, if the insurance companies could able to practice HRM from top to bottom (Chowdhury and Huda, 2014). HRM concept is known to many life insurances in our country having HR related problems such as employees' absenteeism, employees' turnover, improper recruitment \& selection, inadequate training facilities, lack of motivational tools, inadequate welfare facilities, absence of job appraisal system etc (Faruk and Rahaman, 2015). In this case, the life insurance must need to acquire more knowledge of HRM for solving their HR related problems.

Otherwise, the poor applications of HRM will cause a plethora of negative aspects such as, employees' dissatisfaction, absenteeism \& turnover, employees' grievance, low morale, unfavorable working condition, inadequate health \& safety etc. To minimize the above HRM applications, the life insurances should keep an awareness of their employees' absenteeism and turnover, training facilities for their existing employees, practice employees' motivation and adequate welfare facilities for their human resources. Besides, the companies can maintain a job appraisal system in regular basis for minimizing their poor HRM applications.

However, HRM practices assure the recruitment, selection, development, compensation, retention, evaluation, and promotion of personnel within the life insurance that can be the key success factors in future. In this regard, minimizing the poor applications of HRM may be a boon for the HR managers to boost up the organization in term of HR functions and its realistic application within organizations. 


\section{Objectives of the Research:}

The true aim of this study has been identified the present scenario of HRM applications in the insurances in Bangladesh. In this regard, the most concrete directions will cover in this study are:

- To search for the current scenario of HRM application in some selected life insurances in Bangladesh.

- To represent the negative consequences of poor HRM applications in some selected life Insurances in our country.

- To provide some relevant guidelines on the basis of the findings of the study to assure a good HRM applications in those selected life insurances.

\section{Research Questions:}

To address the above stated research objectives, the following study questions will keep in mind throughout this project study:

- What is the recent scenario of HRM practice in some selected life insurances in Bangladesh?

- What are the negative consequences of poor HRM applications in selected life insurances in our country?

- How to assure good HRM applications in life insurance companies in our country?

- What are the current challenges for practicing good HRM in our life insurances?

- Why do many life insurances reluctant to practice a good HRM?

\section{Brief Review of the Related Literature:}

HRM is a set of distinct but associated activities, functions, and processes that are administered at attracting, developing, and maintaining effective workforce (Lado and Wilson, 1994). Additionally, Mishra (2009) argues that, the effective HRM applications can be the determining factor for the triumph of a firm. In view of Lee and Lee's (2007), HRM applications such as proper recruitment \& selection, training and development, teamwork, compensation \& benefit, performance assessment, and employee job security \& satisfaction etc. helps to improve employee's productivity, product quality and the firm's flexibility. In this regard Legge (1995) argue that $\mathrm{HR}$ has a direct impact on the organizational policy and job performance.

According to Arthur (1994) highly commitment human resource activities increase organizational effectiveness by improving working conditions for employees to feel safer in work \& involved in the achievement of the organization's objectives. Huselid (1995) suggests, after investigation over 900 organizations in the US that HR practices can be divided into two categories: first, skill-enhancing HR functions including selection, training, and development are correlated with minimizing turnover and improving financial performance and second, motivation-enhancing pursuit including performance evaluation and compensation activities are associated with measures of productivity. In the word of Dessler and Varkkey (2009) HRM is the process of getting, training, assessing, and compensating employees, and maintaining labor rapport, health and safety, and fairness concern. In this regard, Haslinda, (2009) argues that HRM refers to the policies, practices, and systems that influence employees' behavior, attitudes, and performance.

Additionally, Pfeffer, (1998) views that recruitment and selection is that function of HRM which ensures the success and growth of an organization by taking the employee inside the organization. Again Roy (2008) further points that recruitment is the method of encouraging and examining people to apply for present and anticipated job openings while selection is the system of choosing individuals who have relevant identification to fill present-day and anticipated job openings. Besides, Mondy et al (2005) opines that performance assessment is a formal process of reviewing and assessing individual and team performance. Pfeffer (1998) suggests that soft or high commitment of HR practices generate trust in employees for bringing employees' empowerment and involvement in HR decision making. According to Lee \& Heard (2010) HRM is considered a critical organizational resource that helps an organization sustain its effectiveness with job satisfaction, and organizational commitment. Wayne et al (1997) 
suggests that HRM indicates organization's intentions to cost in employees (such as education, progressive experiences and training) bring higher levels of affective organizational commitment.

In this literature review, one of the prime functions of the life insurance is to act as a risk transfer mechanism related to human life to provide peace of mind and protect against the future losses (Hye, and Rahman, 1997). So life insurance is a big opportunity for our country with a large population and untapped potential (Habibullah, 1999). Indeed, a well developed and evolved life insurance industry is a windfall for economic development as it provides long-term funds for infrastructure development of every economy (Haque 2006). According to Islam and Mamun (2005), after the independent of the People's Republic of Bangladesh in 1971, the government nationalized the insurance company along with the financial institutions in 1972 by Presidential Order No. 95. By virtue of this order, all insurance industries are operating their business under this order.

Life insurance was introduced in our country in the pre-independence period (1971) with the launching of business by American Life Insurance Company, popularly known as ALICO (now MetLife ALICO). Although life insurances have got a massive improvement over the years in Bangladesh with the rapid growth of private insurance companies (BIA 2012). In the word of Rahman (2000) from Bangladesh perspective insurance business was not a promising sector in its early age but it is getting its pace day by day with the growth of overall economic condition of the country. Bangladesh Insurance Association and Bangladesh insurance academy is playing a vital role to keep the insurance business safe and sound in Bangladesh.

\section{METHODOLOGY:}

Research Design - This study has been designed entirely to analyze the research questions to check out the result indicated by the research objective in the context of Bangladesh. Both the quantitative and qualitative data will be used for getting the final result of this research.
Sampling Method - In this study, since all respondents can vary to their status and profession, I have selected the random sampling method to determine the sample size from the population and the total sample size is 220 for getting the best result. Among the total sample respondents, firstly I have estimated the respondents who have not filled up the research questionnaires, then the actual the number of respondents can be finally estimated for the purpose of my research.

Data Collection and Analysis - This paper is based on both primary and secondary data, where primary data were collected through a structured questionnaire on insurance employees. Additionally, convenient sample technique has been applied in case of respondent interview purpose. The target population of this study was employees in Dhaka city who are serving as insurance officials such as junior officers, senior officers and branch managers of different insurance companies. In this study, 10 life insurance companies such as such as American Life Insurance Co. Ltd.; Popular Life Insurance Co. Ltd.; Jiban Bima Corporation Ltd.; Delta Life Insurance Co. Ltd.; Shandhani Life Insurance Co. Ltd.; Meghna Life Insurance Co. Ltd.; Pragati Life Insurance Co. Ltd.; Padma Life Insurance Co. Ltd.; Sun life Insurance Co. Ltd.; Prime Life Insurance Co. Ltd. etc have been selected as sample for collecting primary data in terms of their operational experience, number of employees, premium income and total assets.

The total number of 220 insurance officials has been considered for necessary data focusing on HRM dimensions such as promotion policy, performance evaluation system, employees' commitment, compensation package, job security, training and development, reward and motivation and working environment. The questionnaire was made on considering a five point Likert scale, whereas 1= dissatisfied, 2 = somehow satisfied, $3=$ satisfied, $4=$ moderately satisfied, $5=$ highly satisfied. Moreover, secondary data were considered for the theoretical development of the study, collected from related journals, books, newspapers and internet, etc. In this study, some statistical measures such as, 5 point Likert scale, mean, Rank, and proportion analysis is used to 
analyze the data for the findings of the present scenario of HRM application in the insurance companies of Bangladesh.

Limitations of the Study - In time of conducting this research, especially in data collection, the following limitations can be considered- Firstly, the respondents may be limited to their sample size and composition. Secondly, some respondents may be reluctant to fill up the questionnaires. Thirdly, since data collection is done in Dhaka city only, it may fail to represent the pervasive result for widely used.

\section{RESULTS AND ANALYSIS:}

In this research, the data has been collected from 220 respondents of junior officers, senior officers, and branch managers of the selected life insurance companies, etc. by using a structured survey questionnaire. All the questionnaires have personally administered to each respondent and the response rate was satisfactory. The collected data have analyzed by using simple statistics and results are tabulated and reported in parentages.

Demographic information of the Respondents - In the questionnaires, there is a section concerning respondents' profile to get a general concept about the respondents' gender, age, material status and their professional status etc. A profile of respondents' is presented in the following Table 1. Total number of sample respondents is 220 and 200 respondents have given final research information where male is 120 and female is 80 .

Table 1: Demographic Findings of the Respondents.

\begin{tabular}{|c|c|c|c|c|}
\hline & Frequency & Percentage & Total No. of Respondents & Total Sample Respondents \\
\hline $\begin{array}{l}\text { Gender: } \\
\text { Male } \\
\text { Female }\end{array}$ & $\begin{array}{l}120 \\
80\end{array}$ & $\begin{array}{l}60 \% \\
40 \%\end{array}$ & \multirow{5}{*}{200} & \multirow{5}{*}{220} \\
\hline $\begin{array}{l}\text { Age: } \\
20-30 \\
30-40 \\
40-50\end{array}$ & $\begin{array}{l}100 \\
70 \\
30\end{array}$ & $\begin{array}{l}50 \% \\
35 \% \\
15 \%\end{array}$ & & \\
\hline $\begin{array}{l}\text { Marital Status: } \\
\text { Single } \\
\text { Married }\end{array}$ & $\begin{array}{l}130 \\
70\end{array}$ & $\begin{array}{l}65 \% \\
35 \%\end{array}$ & & \\
\hline $\begin{array}{l}\text { Education: } \\
\text { Graduation } \\
\text { Post graduation }\end{array}$ & $\begin{array}{l}120 \\
80\end{array}$ & $\begin{array}{l}60 \% \\
40 \%\end{array}$ & & \\
\hline $\begin{array}{l}\text { Professional Status: } \\
\text { Junior \& senior officers } \\
\text { Branch managers }\end{array}$ & $\begin{array}{l}180 \\
20\end{array}$ & $\begin{array}{l}90 \% \\
10 \%\end{array}$ & & \\
\hline
\end{tabular}

Source: Field Investigation

The most salient demographic finding according to Table-1 is 120 of respondents $(n=120)$ are male and 80 of respondents $(n=80)$ are female. Out of total respondents, $50 \%$ of the respondents were between 20 and 30 where $35 \%$ of respondents were between 30 and 40 and $15 \%$ of respondents were between 40 and 50 years range. Similarly, $65 \%$ of respondents were single while married accounted for $35 \%$. Most of the respondents were highly educated $(40 \%)$ where Junior and senior officers were $48 \%$, and finally branch managers were $10 \%$.

Respondents' percentage distribution - Now at a glance of 10 selected insurance companies' number of respondents comprised of Junior and senior officers, branch manager etc. and their respective percentage. From the Table 2, the highest respondents were Jiban Bima Corporation Ltd (22.50\%) and the lowest respondents were Sun life Insurance Co. Ltd. 03.50\%); where other insurance companies were a satisfactory response rate. 
Table 2: Respondents' percentage distribution.

\begin{tabular}{|c|c|c|c|c|c|}
\hline $\begin{array}{l}\text { Serial } \\
\text { No. }\end{array}$ & $\begin{array}{c}\text { Name of Selected Insurance } \\
\text { Companies }\end{array}$ & Frequency & Percentage & $\begin{array}{l}\text { Total No. of } \\
\text { Respondents }\end{array}$ & $\begin{array}{l}\text { Total Sample } \\
\text { Respondents }\end{array}$ \\
\hline 01. & American Life Insurance Co. Ltd & 40 & 20.00 & \multirow{10}{*}{200} & \multirow{10}{*}{220} \\
\hline 02. & Popular Life Insurance Co. Ltd & 35 & 17.50 & & \\
\hline 03. & Jiban Bima Corporation Ltd & 45 & 22.50 & & \\
\hline 04. & Delta Life Insurance Co. Ltd & 20 & 10.00 & & \\
\hline 05. & Shandhani Life Insurance Co. Ltd & 14 & 07.00 & & \\
\hline 06. & Meghna Life Insurance Co. Ltd & 13 & 06.50 & & \\
\hline 07. & Pragati Life Insurance Co. Ltd & 10 & 05.00 & & \\
\hline 08. & Padma Life Insurance Co. Ltd & 08 & 04.00 & & \\
\hline 09. & Sun life Insurance Co. Ltd. & 07 & 03.50 & & \\
\hline \multirow[t]{2}{*}{10.} & Prime Life Insurance Co. Ltd. & 08 & 04.00 & & \\
\hline & & Total=200 & Total $=100 \%$ & & \\
\hline
\end{tabular}

Source: Field Survey

HRM application in the life insurance companies Indubitably, According to Mandal (1998) HRM applications in all life insurance companies have become a present demand for the utilization of resources (financial; physical; information; human) through effective planning, motivation, professional development, career development, etc. In addition, Mamun (2015) argue that HRM must be applied for the purpose of HR policy, HR planning, job analysis, job description, job specification, recruitment \& selection, training \& development, job evaluation, performance evaluation, compensation \& benefits, health \& safety, job satisfaction, absenteeism \& turnover etc benefits. Moreover, the most valuable asset of an insurance company is the management knowledge of employees in handling the diverse tasks involved in the delivery of insurance services (Reza and Iqbal, 2007).

Sometimes, the insurance business could be an unthinkable operation lacking of HRM application (Siddiqui et al., 1995). Truly, developing human resources; changing corporate culture, values and the effective utilization of human resources are essential to the success and sustainable development of today's insurance companies in our country (Solaiman and Haque 1999). From the literature study of Nazim-udDin (2013), 15 HRM functions have been identified and administered to the current respondents of 10 selected life insurance companies of our country. All the respondents such as junior officers, senior officers, and branch managers have given their opinion about the prime functions of HRM.

Table 3: Percentage Distribution of HRM practices in the life insurance companies.

\begin{tabular}{|l|l|c|c|c|c|}
\hline S. N. & HRM applications in life insurance companies & Frequency & Percentage & Ranks & $\begin{array}{c}\text { Total } \\
\text { Respondents }\end{array}$ \\
\hline 01 & Fair compensation \& benefit facilities & 22 & 11.00 & 03 & \\
\hline 02 & Training \& development facilities & 25 & 12.50 & 02 \\
\hline 03 & Proper recruitment \& selection & 31 & 15.50 & 01 \\
\hline 04 & Proper motivation \& leadership & 09 & 04.50 & 10 \\
\hline 05 & Morale \& ethics of employees & 08 & 04.00 & 11 \\
\hline 06 & Proper HR policy and planning & 15 & 07.50 & 06 \\
\hline 07 & Employees' absenteeism \& turnover & 03 & 01.50 & 15 \\
\hline 08 & Performance rating system & 17 & 08.50 & 05 \\
\hline 09 & Adequate welfare, health \& safety facilities & 13 & 06.50 & 07 \\
\hline 10 & Employee's job satisfaction & 12 & 06.00 & 08 \\
\hline 11 & Proper working environment & 06 & 03.00 & 12 \\
\hline 12 & Employees' job stress & 04 & 02.00 & 14 & \\
\hline
\end{tabular}




\begin{tabular}{|c|l|c|c|c|}
\hline 13 & $\begin{array}{l}\text { Top management commitment and positive } \\
\text { attitude }\end{array}$ & 10 & 05.50 & 09 \\
\hline 14 & Fair promotion \& career growth & 20 & 10.00 & 04 \\
\hline 15 & Fair job evaluation method & 05 & 02.50 & 13 \\
\hline
\end{tabular}

Source: Field survey

From the analysis of the above table it is observed that, on the basis of the questionnaire survey, total 15 HRM functions have been identified from the literature reviews and all HRM functions are ranked based their frequency and percentage distribution for finding the most important practicing functions by our different life insurance companies (Table 3). The highest percentage indicates the highest rank among the above $15 \mathrm{HR}$ practicing functions. So the HRM functions by their percentage and rank are proper recruitment and selection $(15.50 \%)$; training and development facilities (12.50\%); fair compensation and benefit facilities (11.00\%); fair promotion and career growth (10.00\%); performance assessment system $(8.50 \%)$; human resource policy and planning $(7.50 \%)$; adequate welfare, health \& safety facilities (6.50\%); employee's job satisfaction (6.00\%); top management commitment and positive attitude (5.50\%); proper motivation \& leadership (4.50\%); morale \& ethics of employees $(4.00 \%)$; proper working environment (3.00\%); fair job evaluation method (2.50\%); employees' job stress (2.00\%); employees' absenteeism \& turnover $(1.50 \%)$.

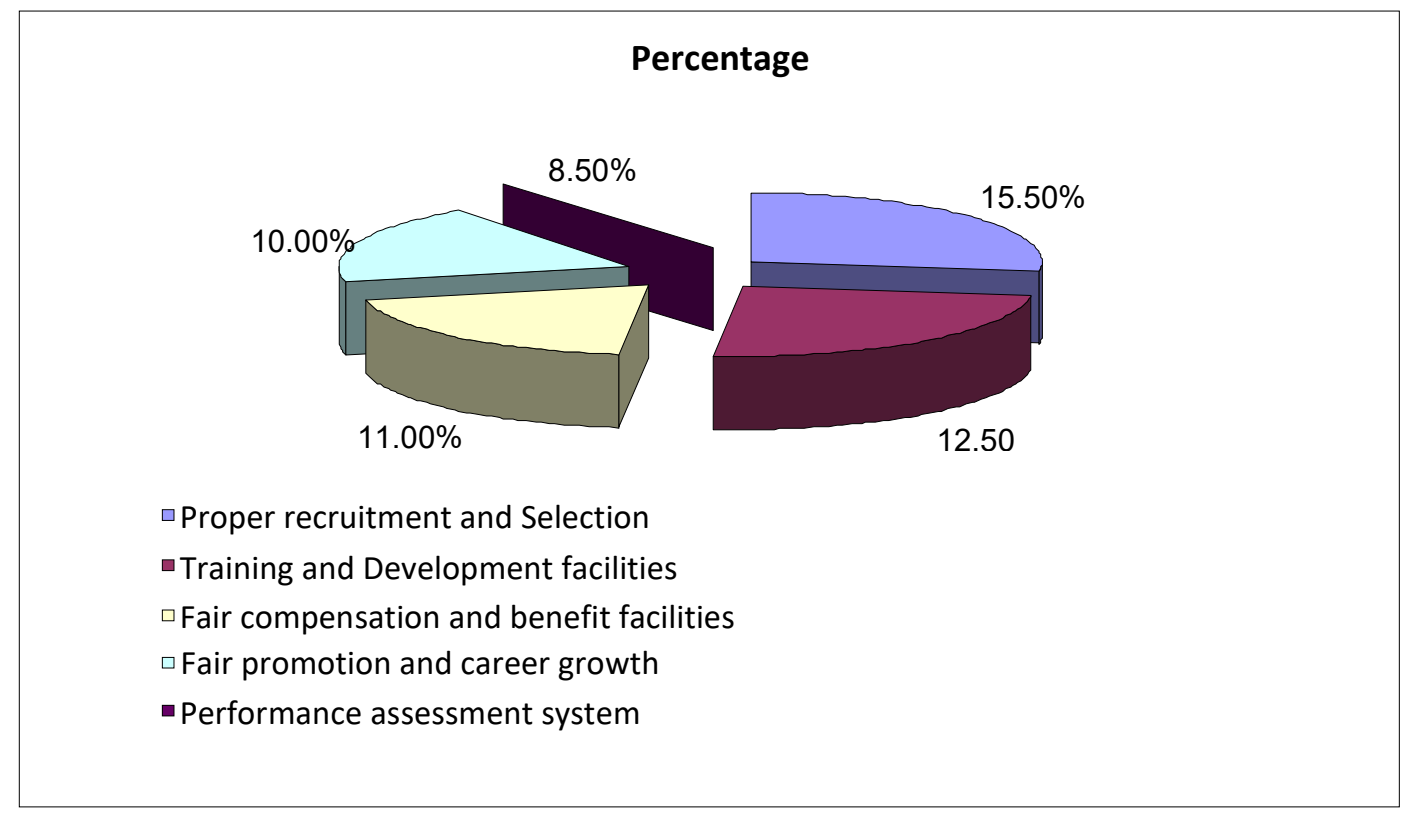

Fig 1: Five major HRM practices in life insurance companies found from percentage Distribution.

The above pie chat (Fig 1) represents five major HRM functions by the life insurance companies in our country are proper recruitment and selection $(15.50 \%)$; training and development facilities (12.50\%); fair compensation and benefit facilities $(11.00 \%)$; fair promotion and career growth $(10.00 \%)$; performance rating system $(8.50 \%)$.

Present scenario of HRM applications in life insurance companies - From the literature review, it is very clear that, the present scenario of HRM applications in the various life insurance in our country is not well defined and satisfactory. Still HRM practice cannot bring positive effect on the productivity of insurance organizations and employees' satisfaction overall. According to Nazimud-Din (2013), the present scenario of HRM applications in the various life insurance is very poor for the following reasons - 
Table 4: Present scenario of HRM applications in life insurance companies.

\begin{tabular}{|l|l|}
\hline Causes of poor HR applications of insurance companies in BD & Mean \\
\hline Employees' absenteeism & 2.3141 \\
\hline Employees' turnover & 1.6282 \\
\hline Inadequate training facilities & 1.5641 \\
\hline Lack of Motivational tools & $\mathbf{1 . 1 3 4 6}$ \\
\hline Low morale of employees & 1.3974 \\
\hline Managerial inefficiency & 1.7115 \\
\hline Negative role of trade union & $\mathbf{1 . 1 2 8 2}$ \\
\hline Lack of proper planning \& implementation & 2.9295 \\
\hline Inadequate welfare facilities & 3.1026 \\
\hline Absence of performance evaluation system & 2.1603 \\
\hline Lack of friendly working environment & 2.9103 \\
\hline Unfavorable attitude of employees toward company & 3.3718 \\
\hline Employees' job stress & 3.3205 \\
\hline Lack of top management commitment and positive attitude & $\mathbf{1 . 1 2 1 8}$ \\
\hline lack of fair promotion & 2.0000 \\
\hline Absent of career growth and development & $\mathbf{1 . 3 2 0 5}$ \\
\hline Absence of goal-based performance & $\mathbf{1 . 3 5 2 6}$ \\
\hline Technology phobia & 2.7564 \\
\hline
\end{tabular}

Source: Field Investigation

The above Table 4 shows that the most crucial variables that influence poor HRM applications in life insurance companies in our country (The mean values of these crucial variables are 1.1218, 1.1282, 1.1346, $1.3205,1.3526$, and respectively) such as lack of top management commitment and positive attitude; negative role of trade union; lack of motivational tools; absent of career growth and development; absence of goal-based performance, etc.

\section{Suggesting Improvements:}

From the literature review and respondents' data analysis, life insurances of our country are enjoying the benefits of HRM as a blessing part of properly managing their insurance business. However, our life insurance companies can concentrate on the following measurable steps about the proper utilization of HR functions -

1) Firstly, all the life insurances should follow the proper recruitment and selection methods for choosing and selection the right personnel in right place. Companies should maintain a strong fair and unbiased selection policy from the top to bottom. In this case, all the life insurance companies need top management commitment and positive attitude to maintain the proper recruitment and selection method.

2) Secondly, more training facilities all the life insurance companies should introduce for the newly recruited employees for getting their optimum level of outcomes by keeping a management development policy, motivation, recognition, acknowledgement, reward and positive appraisal from the top management as a part of their succession planning.

3) Thirdly, Fair compensation and benefit facilities for the employees must be introduced in all the life insurance companies in our Bangladesh in association with equal employment opportunity; active role of trade union ultimately.

4) Fourthly, all the life insurances should maintain a fair promotion based on the employees' job performance, seniority and merit to keep a clear career growth and development policy for their employees.

5) Finally, all the life insurances should keep a fair performance assessment system in all levels of management given priority to goal-based performance method of appraisal system for the full phase utilization of HRM functions. 


\section{CONCLUSION:}

In summary, from the above research findings, the current scenario of HRM applications in the life insurance companies in our country is not in a satisfactory level due to having some shortcomings such as employees' absenteeism, employees' turnover, inadequate training facilities, lack of motivational tools, inadequate welfare facilities, absence of performance rating system, etc. The study recommended a few logical issues for our life insurance companies to reduce this poor situation by applying good HRM applications to ensure more profit and reputation. In this regard, according to Uddin and Khan (2005), both the general and life insurance companies should apply HRM functions for reducing their employees' absenteeism and turnover; can arrange adequate on the job and off the job training facilities for their existing employees; can practice a positive motivation and adequate welfare facilities; can maintain a performance assessment system in regular basis for minimizing this current unsatisfactory scenario of HRM practice. Last but not least; HRM can be an ultimate compact solution of all life insurance companies' HR related problems by realizing that $\mathrm{HR}$ is the best resource among all other resources such as financial resource, physical resource, information resource or $6 \mathrm{M}$ (men, machine, material, money, market and method). The research findings have assisted us to realize the importance of HRM application in all insurance companies to assure the full utilization of human skills in work by thinking that human is a capital not a liability or burden at all.

\section{ACKNOWLEDGEMENT:}

Authors would like to thank Jatiya Kabi Kazi Nazrul Islam University, Trishal, Mymensingh, Bangladesh authority for providing all types of facilities to perform this study.

\section{CONFLICTS OF INTEREST:}

The author declares that they have no competing interests with respect to the research.

\section{REFERENCES:}

1. Ahmed, S.U. (1977). "Insurance Business in Bangladesh: A Study of the Pattern, Problems
\& Prospects", Bureau of Business Research, University of Dhaka, Bangladesh.

2. Ali, A., (2013). Significance of human resource management in organizations: linking global practices with local perspective. Researchers World Journal of Arts, Science \& Commerce, 4(1), 78-87. https://ssrn.com/abstract=2210640

3. Becker, G. S. (1993). Human capital: A theoretical and empirical analysis. New York: Free press.

4. BIA (2012). Bangladesh Insurance Association. Welcome to Bangladesh Insurance Association. Retrieved March 25, 2012, from BIA Homepage: http://bia-bd.org/pdf/balane sheet life2010.pdf.

5. BIA (Bangladesh Insurance Association) (2000). "Bangladesh Insurance Academy." Insurance Journal, Vol.51.

6. Charumathi B. (2012). On the Determinants of Profitability of Indian Life Insurers-An Empirical Study. Proceedings of the World Congress on Engineering, Vol I, U.K.

7. Chowdhury, T.A. and Huda, F., (2014). Performance evaluation of selected private life insurance companies in Bangladesh. The International J. of Business \& Management, 2(6), 318.

8. Dessler, G. \& Varkkey, B. (2011b). Fundamentals of human resource management content, competencies and applications. India: Dorling Kindersley Pvt.

9. Ejaz, S. and Akbar, W., (2015). An effectiveness of human resource management practices on employee retention findings from insurance companies of Karachi. European Journal of Business and Management, 7(7), 27-33. https://www.iiste.org/Journals/index.php/EJBM/a rticle/view/20518

10. Faruk, O. and Rahaman, A., (2015). Measuring efficiency of conventional life insurance companies in Bangladesh and takaful life insurance companies in Malaysia: A nonparametric approach. Management Studies and Economic Systems, 54(2648), 1-16

11. Habibullah, M. (1999). "On Developing Quality Service in Insurance Industry” Insur- 
ance Journal, Bangladesh Insurance Academy, pp.7-11.

12. Habibullah, M. and Ghosh, S.N. (1989). "General Insurance Business in Bangladesh: An Appraisal of the Performance of Sadharan Bima Corporation" Bureau of Business Research, University of Dhaka, Dhaka, Bangladesh.

13. Haque, N. A. (2006). Need for professionalism in insurance sector. Insurance Journal, 37-49.

14. Haslinda, A. (2009). Evolving terms of human resource management and development. The Journal of International Social Research, 2(9), 180-186.

http://www.sosyalarastirmalar.com/cilt2/sayi9pdf /haslinda.pdf

15. Huselid, M. (1995). The impact of human resource management practices on turnover, productivity, and corporate financial performance. Academy of Management Journal, 38(3), 635-672.

16. Hye, M. A. and Rahman, M. A. (1997). "Performance of Selected Private Sector General Insurance Companies in Bangladesh" Chittagong University Studies (Commerce Volume), 13, 137-160. https://doi.org/10.18034/abr.v1i1.142

17. Islam, N. and Mamun, M.Z. (2005). "Factors for Not Buying Life Insurance Policies in a Developing Country"- A Case of Bangladesh", J. of Business Administration, University of Dhaka, Bangladesh, pp.1-22.

18. Jony MTI, Alam MJ, and Rana MS. (2019). Customers' Satisfaction of Service Quality: A Study on the Customers of DBBL at Different Areas of Mymensingh District. Can. J. Bus. Inf. Stud., 1(5), 10-16. https://doi.org/10.341\%2004/cjbis.019.01016

19. Khnodkar, M. and Rahman, M (1993). "Trends of Financial Indicators of Insurance Industry: A Case Study", Journal of the Institute of Cost and Management Accountants of Bangladesh, The Cost and Management, 21, 6 .

20. Koch, M.J. and McGrath, R.G. (1996). 'Improving Labor Productivity: Human Resource Management Policies Do Matter', Strategic Management Journal, 17, 335-54.
21. Kundu, S.C. and Malhan, D., (2009). HRM practices in insurance companies: A study of Indian and multinational companies. Managing Global Transitions, 7(2), pp.191-215.

22. Lado, A. A., \& Wilson, M. C. (1994). Human resource systems and sustained competitive advantage: A competency-based perspective. Academy of Management Journal, 19, 699-727. https://www.jstor.org/stable/258742?seq=1\#meta data info tab contents

23. Lee, F., \& Lee, F. (2007). The relationships between HRM practices, leadership style, competitive strategy and business performance in Taiwanese steel industry. Paper presented at the 13th Asia Pacific Management Conference, Melbourne, Australia.

24. Lee, S. H., \& Hard, A. (2000). A managerial perspective of the objectives of HRM practices in Singapore: An exploratory study. Singapore Management Review, 22, 65-82.

25. Legge, K (1995). Human Resource Management: Rhetorics and realities, Macmillan, London.

https://www.macmillanihe.com/page/detail/Huma n-Resource-Management/?K=9781403936004

26. Mamun, Z.M., (2015). Ethical Standards in Life Insurance Companies in Bangladesh: The Policy Holders' View.

27. Mandal, M.G. (1988). "Insurance Industry in Bangladesh-An Overview”, Insurance Journal, Bangladesh Insurance Academy, 49: 22.

28. Mishra, M.N. (2009). "Insurance: Principles and Practices" Sultan Chand and Company Ltd., New Delhi.

29. Mondy, R.W., \& Noe, R. M. (2006). Human resource management $\left(9^{\text {th }}\right.$ Ed.). India: Dorling Kindersley.

30. Nazim-ud-Din, M., (2013). HR practices in insurance companies: A case study of Bangladesh. Abasyn J. of Social Sciences, 6(2), 77-90.

https://docplayer.net/12767426-Hr-practices-ininsurance-companies-a-case-study-of-bangla desh-mohammad-nazim-ud-din.html

31. Pfeffer, J. (1998). The human equation: Building profits by putting people first. Boston MA: Harvard Business School Press. 
32. Rahman, M.M. (2000). "Insurance Industry in Bangladesh and its Future prospects" Journal of Business Administration, University of Dhaka, Bangladesh, pp.121-131.

33. Reza, S.M., and Iqbal, M.M., (2007). Life insurance marketing in Bangladesh.

34. Roy, P.K. (2008). "Prospects and Problems of Insurance Sector in Bangladesh: Challenges Ahead", Paper presented in a seminar at Dhaka.

35. Siddiqui, Hafiz G.A.; Islam, M.S., and Chowdhury, M.J.A. (1995). "Life Insurance Business in Bangladesh-An Evaluation" Insurance Journal, Bangladesh Insurance Academy, Dhaka, Vol.47.

36. Solaiman, M., and Haque, M.A. (1999). "Developing of Insurance Industry in Bangladesh: An Innovative Approach”, Insur- ance Journal, Bangladesh Insurance Academy, pp.43-48.

37. Stavrou-Costea, E. (2005). The challenges of human resource management towards organizational effectiveness. Journal of European Industrial Training, 29(2), 112 - 134. https://doi.org/10.1108/03090590510585082

38. Uddin, M.N., and Khan, M.S.U. (2005). "Performance Evaluation of Some Private Sector General Insurance Companies in Bangladesh." The Chittagong University J. of Business Administration, 20: 349-366.

39. Wayne, S. J., Shore, L. M., \& Liden, R. C. (1997). Perceived organizational support and leader-member exchange: A social exchange perspective. Academy of Management Journal, 40, 82-111. https://doi.org/10.2307/257021

Citation: Milon M., (2019). Present scenario of human resource management (HRM) practices in the life insurance companies: Bangladesh perspective. Can. J. Bus. Inf. Stud., 1(6), 17-27. https://doi.org/10.34104/cjbis.019.01727 (c) 